\title{
Books
}

\section{BIM for project} managers

by Peter Barnes, published by ICE Publishing, 2020, f50, reviewed by Julie Wood, Arup, UK

The author starts by pointing out that the acronym 'BIM' (for building information modelling) is now commonly used to define digital technology across the wider construction and infrastructure industries.

He then stresses the importance of getting the BIM strategic brief right, providing a helpful set of prompts for the project manager to take into consideration when working with the employer. This comes to life by the use of examples from real projects.

The author sets out the headline BIM management roles including information manager, built asset security manager and BIM coordinator This adds granularity that will be very helpful to project managers, particularly at project set-up stage. He next discusses the different project stages. I found the chapter on collaboration to be the most helpful, reinforced by a case study of the Bergen Light Railway extension.

Overall, this is a well-put-together book, very readable and relevant to project managers at all stages in their careers.

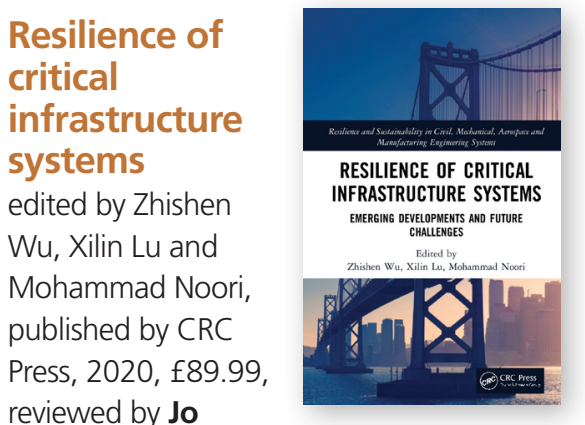

Griffiths, Network Rail, UK
This book is a collation of selected papers as presented at the second international workshop on infrastructure resilience held in the latter part of 2018 in China.

Chapter 1 explains how the workshop focused on specific research questions around risk control and quantification, the use of emerging technologies for prediction of infrastructure behaviour, and big data and machine learning. The following chapters are informative papers on resilience on a variety of topics from the life cycle of civil infrastructure to bridge decks, historical timber bridges, concrete structures, seismic resilience and fibrereinforced polymers.

I was particularly interested in big data and how we can use this to predict and prevent or prepare for severe events. This makes it clear that engineers of the future must start to consider the impacts of climate change and the future impact this has on our water supplies, transportation networks, energy grids and buildings.

\section{The urban}

planning imagination

by Nicholas Phelps, published by Wiley, 2021, f55, reviewed by Claudia Currie, Mott MacDonald, UK

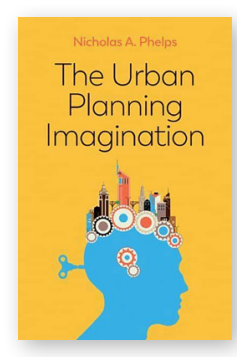

The author is an international planning lecturer, but this book has been written to take non-technical readers on a journey through the ethos behind urban planning across the world.

After touching on the need for both a legally binding and strategic planning framework, he emphasises the need for imaginative thinking to be combined with continuous shaping of the future urban landscape.

The author draws attention to the need to ensure that stakeholders, now called 'interested parties' or 'actors', are involved in all stages of the consultation process. He then turns to summarising lessons learnt, including some failures, and provides international examples - although these are not in exhaustive detail.

Overall, it is an easy read for anyone who wants to get an insight into how planning can influence engineering solutions. The final chapter concludes that history and geography both have strong influences on planning outcomes, but challenges how this should be used to draw up plans for the future.

\section{Earthquake} engineering for concrete dams by Anil Chopra, published by Wiley, 2020, f110, reviewed by Alpa Sheth, VMS consultants Pvt, Ltd, Mumbai, India

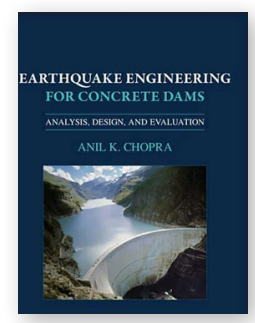

In 1967 an earthquake significantly damaged the Koyna concrete gravity dam in India, in an area considered until then to have low seismic hazard. It also shook the community of dam engineers across the world. On revisiting similar dams in the USA, it was realised they could sustain more seismic damage than estimated by traditional analysis and design procedures using pseudo-static methods.

This book starts from the lessons learnt from the seismic performance of the Koyna dam. It then documents the transition of analysis and design of concrete gravity dams, from pseudo-static analysis procedures to state-of-art dynamic analysis methods for dam, water and foundation interaction. The shortcomings of earlier dynamic analysis procedures are discussed and suggestions are made for alternative methods to overcome them.

The book is divided into three main sections - gravity dams, arch dams, and design and evaluation procedures. Each section is exhaustive in its coverage. It will be invaluable for structural design engineers involved or interested in the retrofit or design of concrete gravity dams. 


\section{MONITOR Books}

The ICE Library maintains one of the most comprehensive collections of civil engineering books in the world, including all titles from ICE Publishing (shown in bold below). New books acquired in the past 3 months include the following (* indicates e-book only).

\begin{tabular}{|c|c|c|}
\hline Advanced soil mechanics & F Hejazi and T Chun & f74.99 \\
\hline Applied strength of materials (7th ed.) & R Mott and J Untener & f140.00 \\
\hline Catastrophe and systemic change* & G Kernick & f18.99 \\
\hline CDM 2015: questions and answers (4th ed.) & P Perry & f60.00 \\
\hline Chances and risks in construction management and economics & C Hofstadler and M Kummer & f119.99 \\
\hline Chatham historic dockyard & N Cossons (ed) & f19.95 \\
\hline City and transportation planning: an integrated approach & A Morimoto & $f 100.00$ \\
\hline Design for zero & J Orr et al. / IStructE & f45.00 \\
\hline Design of highway bridges (4th ed.) & R Barker and J Puckett & f145.00 \\
\hline Dynamics of soils and their engineering applications* & S Saran & f170.00 \\
\hline Engineered transparency & B Weller and J Schneider & f45.00 \\
\hline Engineering aspects of Howrah bridge in Kolkata (1943)* & A Ghoshal & f44.99 \\
\hline Essentials of construction planning and scheduling & G Robertson & f55.00 \\
\hline Ethics for engineering* & A Bainbridge & $£ 44.99$ \\
\hline eWork and eBusiness in architecture, engineering and construction & V Semenov and R Scherer (eds) & f175.00 \\
\hline Forensic engineering (2nd ed. $)^{*}$ & S Petty (ed) & f140.00 \\
\hline Fundamentals of structural dynamics & Z Zhou et al. & f135.00 \\
\hline Geotechnical aspects of underground construction in soft ground & M Elshafie et al. (eds) & f222.99 \\
\hline Grenfell and construction industry reform & S Phillips and J Martin & f34.99 \\
\hline Handbook of catchment management ( 2 nd ed.) & R Ferrier and A Jenkins (eds) & f140.00 \\
\hline Handbook of water harvesting and conservation (2nd ed.) & S Eslamian and F Eslamian (eds) & f120.00 \\
\hline Humanitarian civil engineering & G Kremmyda (ed.) & f39.50 \\
\hline Hydraulics in civil and environmental engineering (6th ed.) & M Borthwick et al. & f56.99 \\
\hline ICE pocket guide to steels in the built environment & S Hall & $f 45.00$ \\
\hline Managing energy use in modern buildings & B Flaman and C McCoy (eds) & f45.00 \\
\hline Manual on scour at bridges and other hydraulic structures - supplementary guide & Ciria & $f 70.00$ \\
\hline Ocean wave dynamics for coastal and marine structures & V Sundar & f85.00 \\
\hline People flow in buildings & M Siikonen & f99.95 \\
\hline Planning resilient infrastructure systems & A Hay & $f 70.00$ \\
\hline Port maintenance handbook & G Steele & f70.00 \\
\hline Power plant engineering & F Zabihian & f120.00 \\
\hline Project benefit realisation and project management & $\mathrm{R}$ Young and $\mathrm{V}$ Zerjav & f54.95 \\
\hline Project management, planning and control (8th ed.) & A Lester & f76.95 \\
\hline Rapid excavation and tunneling conference 2021 proceedings* & J Carlson and G Davidson (eds) & f201.00 \\
\hline Reinforcement of timber elements in existing structures & J Branco et al. (eds) & f109.99 \\
\hline Shield tunnel engineering & S Wang et al. & f134.00 \\
\hline Slurry systems handbook (2nd ed.) & B Abulnaga & f120.99 \\
\hline Spiritual significance in Islamic architecture & M Badawi & f24.99 \\
\hline Structural reliability* & Y Zhao and Z Lu & f99.95 \\
\hline Sustainable construction in the era of the fourth industrial revolution* & C Aigbavboa et al. & f140.00 \\
\hline The architecture of British bridges* & $\mathrm{R}$ Yee & $f 20.00$ \\
\hline The handbook to building a circular economy (2nd ed.) & D Cheshire & f30.00 \\
\hline Timber connections: a guide for engineers. Part 1: theory* & K Ranasinghe / BM Trada & $f 30.00$ \\
\hline Urban playground & T Gill & f38.00 \\
\hline Vibration mitigation systems in structural engineering* & O Altay & f140.00 \\
\hline Why do buildings collapse in earthquakes? & R Spence and E So & f79.95 \\
\hline
\end{tabular}

All books can be borrowed through the library's online catalogue at www.ice.org.uk/knowledge-and-resources/ice-library or from the ICE Members' Resource Hub on the second floor of 1 Great George Street, London, SW1P 3AA from 9.15 a.m. to 5.30 p.m., Monday to Friday (subject to Covid-19 restrictions https://www.ice.org.uk/ice-covid-19-policy).

Recent ICE Publishing titles can also be purchased from the ICE Members' Resource Hub or ordered by calling +44 1235465577 , emailing orders@icepublishing.com or by visiting www.icevirtuallibrary.com/content/books. 